\title{
The Study on the Construction of College English Smart Class in Private College
}

\author{
Chunfang Chen \\ Foreign Language School \\ Huanghe Science and Technology College \\ Zhengzhou, China
}

\begin{abstract}
Information technology plays an important role in education and the wise educational concept arises at the historic moment. Thus the smart class becomes the main base to realize wise education. This article mainly study on the definition and characteristics of smart class and how to make use of a new generation of information technology to build the college English smart class in private college.
\end{abstract}

Keywords-educational informatization; information technology; wise educational concept; college English smart class

\section{INTRODUCTION}

The 13th Five-Year Plan of Educational Informatization of the Ministry of Education clearly states that information technology plays an important role in education and the revolutionary influence to it has become increasingly evident. Educational Informatization is enjoying great historical opportunities for development. President Xi Jinping points that we should promote the innovational development between the information technology and education on congratulations to the 1 st international conference of Educational informatization. Thus the wise educational concept arises at the historic moment, and the smart class becomes the main base to realize wise education. The core of the smart class is to change and improve the classroom teaching mode with the latest information technology, to solve the long existing problem in the traditional classroom teaching. However, most of the existing researches are still about the ideas of smart class level or the technical description, and the study on the construction of English smart class in private college is not enough. According to the above background, the study on how to make use of a new generation of information technology to build the English smart class in private colleges, to promote the college English teaching organization and the reform of students' learning style, has important theoretical and realistic significance.

\section{DEFINITION AND CHARACTERISTICS OF SMART CLASS}

\section{A. Definition of Smart Class}

About the concept of smart class, there is still no unified definition. Many domestic scholars have different understanding from different angles. Tang Yewei states that with the support of information technology, the smart class is to construct the personalized, wise, and the digital teaching environment through changing teaching methods, and integrating technology into classroom teaching, so as to promote the cultivation of wisdom ability in the class effectively (Tang Yewei, 2014). Sun Shuhui and Liu Bangqi point out that based on constructivism learning theory, the smart class is using the Internet, big data, cloud computing and Internet of things to build the intelligent and efficient class (Sun Shuhui, Liu Bangqi,2015).

To sum up, based on these definitions, the author thinks that with the aid of modern information technology such as online open course platform, the application of college English smart class teaching mode is to emphasize the combination of mobile terminals and the classroom, promote the development of the students individuation and wisdom through teaching and learning of smart class, and realize the efficient English teaching and learning mode of whole process(before the class, in the class and after the class). About the teaching characteristics, the English smart class and the traditional class have essential difference. English teachers are the centers in the Traditional English class and their main task is to teach knowledge. While in the smart class, English teachers are the guiders for the perplexed problems and they focus on the individual difference among students. Students are learning in a personalized and intelligent way.

\section{B. Characteristics of Smart Class}

The appearance and development of smart class is, in fact, the result of college education informatization focusing on teaching, classroom, and the activities between teachers and students (Cui Xiaohui, Zhu Xuan, 2016). Smart class has the following features:

1) Digital teaching decision: The smart class is always supported by the information technology platform constructed by the college, and based on the collection and exploration of dynamic learning data. The whole process and effect of students' learning are presented digitally. It makes the teaching process change from relying on the teacher's teaching experience to relying on the objective data in the teaching. And on the basis of the data, the teachers grasp the learning situation accurately, and make 
the decision based on the data. The traditional class teaching mainly depends on the teacher's personal teaching experience to judge the students' learning behavior, and then designs the process of teaching. The smart class is to adjust the teaching strategy according to big data's excavation and analysis of students' learning behavior.

2) Instant evaluation feedback: The teaching mode of smart class adopts the evaluation of dynamic accompanying learning, that is, dynamic learning diagnosis and evaluation which runs through the whole process of classroom teaching, including pre-study assessment and feedback, classroom real-time testing and evaluation and instant feedback, and after-class homework evaluation and tracking feedback, thus it achieves the real-time, dynamic diagnosis and analysis and evaluation information feedback to reconstruct the formative teaching evaluation system. The data mining can make teachers accurately predict the learners' potential learning needs. The creation of virtual situation enables students to enter the learning state more quickly. The learning resources that the teachers give in advance can meet the needs of students in the first time.

3) Three-dimensional interaction: As the cooperative inquiry class, the exchange and interaction of smart class teaching is more vivid and flexible, and the information communication between teachers and students, students and students are diversified. In addition to the interaction between teachers and students in the classroom, teachers and students can also make full use of the cloud platform to get the extra-curricular exchanges, information exchange and interaction at anytime, anywhere, so as to realize the continuous communication. Group services in the smart class can help learners with the same learning needs and interests to automatically form learning communities. Teachers and students can also break through the traditional class' time-space constraints to achieve convenient online communication.

4) Various online resources: The smart class provides learners with a variety of multimedia resources, including micro video, electronic documents, pictures, voice, web pages, and so on. According to the evaluation analysis of pre-test in the process of previewing and the quiz in class, the teacher makes the teaching plan and the guidance strategy pertinently, pushes the individualized studying material, and realizes the individualized teaching service, which also meets the learners' individual learning needs, helps students to strengthen and complement the weak points and improves the learning effect.

\section{PROBLEMS EXISTING IN TRADITIONAL COLLEGE ENGLish TEACHING IN PRIVATE COLLEGE AND THE NECESSITY OF CONSTRUCTING COLLEGE ENGLISH SMART CLASS UNDER THE BACKGROUND OF EDUCATIONAL INFORMATIZATION}

To the non-English major students in private colleges, their English foundation is weak and they aren't interested in learning, so their learning enthusiasm and participation is not high, besides, many teachers use the traditional way of teaching, which result in the poor teaching effect. What we are familiar with the traditional classroom often is this: the teachers finish the preparation about the class activities according to the teaching experience before the class; while in the class, the teachers teach the new knowledge to the students in a planned way, some students listen and record carefully, but others listen sleepily. The teacher will ask some questions in the teaching process. If the student's answer is just the exact one, he or she will be praised; otherwise, the teachers will continue to ask the next student until they get the answer they want to have. A few students have the opportunity to speak, and based on the answers, the teachers' just judge whether the students grasp it or not. After all, the inference is one-sided. Because the teachers can't consider each student's needs, some students lose interest and become absent-minded. The class is successful if the teachers can finish all the tasks they have prepared and students can answer the questions with one voice, which also means that teachers and students interact frequently. After class, the students complete the homework on time. A few outstanding students will find difficult questions to solve. Some students feel that the learning is boring, and they often copy homework.

There are some limitations about this traditional class. Firstly, it is based on the empirical analysis of learning situation. Secondly, it belongs to the stereotyped teaching presupposition and asymmetrical one-way communication. Besides, the learning process of the students is always the same and the feedback is cursory and blind. It is difficult to solve these limitations in the traditional way, while the "smart class" provides the possibility to solve the problem.

\section{A. Smart Class can Realize the Individualized Teaching of College English}

With the help of abundant teaching resources, college English smart class can make individualized teaching plan for students, meet students' learning needs, and fully integrate students' classroom activities. At the same time, it can enrich English teaching content and promote students to learn English better by modern analysis tools of big data. First, smart class provides students with more abundant English teaching resources. According to the level of students' learning ability, teachers can prepare different teaching materials for students and promote students to better understand the difficulties of knowledge. Besides, they can form individualized teaching paths and play the role of different methods of English pedagogy to realize the individual guidance of different students, and finally to achieve the goal of common progress, which will improve the efficiency of college English teaching. In addition, teachers can also carry out innovative education according to the students' ability needs to promote the students to explore the English knowledge from their own interest. 


\section{B. Smart Class Expands the Students' English Learning Thinking}

In the end, every teaching mode should play an important role in expanding students' learning thinking. It should not only enable students to master basic English knowledge, but also enable students to form systematic English learning thinking ability and develop students' good learning habits to form a correct metacognition of English learning activities (Dickinson, L.1987). Firstly, smart class teaching can select teaching methods according to students' personal characteristics, thus it can cultivate students' ability to solve specific problems. What's more, smart class teaching helps teachers to understand students' English learning situation in depth and establish a more scientific and effective feedback mechanism by arousing students' active participation consciousness and forming positive interaction between teachers and students, which helps students to improve their self-cognition. Most importantly, students can fully understand their interest in the process of smart class teaching activities. In this way, it can help students to make more scientific learning plans, and promote students to learn English more efficiently.

\section{Smart Class Provides a Colorful Learning Model for Students}

The key of successful college English class teaching mode lies in forming effective communication between teachers and students in a good classroom atmosphere, helping students to form a better English learning experience and comprehensively improving the quality of students' English learning (BensonK,1997). In the smart class teaching model, the popular classroom teaching mode, such as "micro-class" and "flipped class" can be applied to English teaching to meet the needs of students better. In addition, the traditional teaching environment has been developed to improve the selectivity of students' learning to meet the needs of students' flexible learning, and improve the students' learning efficiency. Thirdly, the management mode of classroom teaching has been innovated, and the smart class will achieve the goal of combining English practice and speaking in class. It also helps to promote students' practice of listening, speaking, reading and writing better in English class.

\section{The PATH OF CONSTRUCTING COLLEGE ENGLISH SMart Class in Private College}

The construction and implementation process of smart class consists of three sections: before class, in class and after class. The core of it is intelligent pushing of learning resources and design of task sheet before class. The key of it is positive interaction between teachers and students in class. The focus of it is personal counseling and intelligent tracking after class.

\section{A. Intelligent Pushing of Learning Resources and Design of Task Sheet before Class}

There are a lot of teaching resources about English courses that make use of modern information technology and network technology. They provide high-quality educational resources about sharing and individualized teaching resources services for teachers and students in colleges and the general public. They can browse, search and reorganize resources. At the same time, they have the function of evaluation, interactive participation and "teaching" and "learning". Before class teachers guide students to log into the flip campus with the computer or mobile phone, and students can enter to find the course they want in the resource-sharing search, and then they can see all the teaching resources, such as the whole course video. Teachers can ask students to finish the pre-class task sheet after watching the video. The pre-class task sheet is carefully prepared by the teacher before class, and the electronic version is sent to the qq or wechat with a mobile phone. Students are required to finish before class.

\section{B. Design of Teaching Activities in Class}

From the teaching method, smart class makes full use of the traditional model, the new online and offline mode. The online mode mainly uses the word platform Scallop, BaiCiZhan and flipped class carrying out effective teaching activities, and the offline mode mainly adopts the traditional teaching mode. From the teaching content, based on the fragmental learning, knowledge will be condensed in the micro lesson in order to improve students' learning interest. From the time of teaching design, teachers speak less, but students speak more clearly.

\section{Personal Counseling and Intelligent Tracking after Class}

The main task after class is to examine, including students and teachers. Students are mainly about the online and offline homework assessment. The teachers assign a bibliography; the students complete the task of reciting words every day and typing cards to show completion on the qq or wechat. Students finish their homework after class on the net (www.pigai.org ).Here students can make mutual comments on each other's composition or translation, which mobilize the students' enthusiasm completely. In addition to the automatic and rapid review, the pigai network also gives feedback on the similarity and source of the composition. Now teachers can give the feedback on students' homework immediately after browsing the pigai network which is helpful for the re-verification of teaching effect and the following activities after class.

\section{CONCLUSION}

The English smart class teaching model has brought about a new teaching reform. But the learning evaluation in the model attaches importance to the process evaluation and it's difficult to make the students adapt to this kind of evaluation. Otherwise, no matter how colorful the pre-class learning resources that pushed forward in advance are or how sophisticated the designed homework is, it will fail because it is ignored by students. The lack of positive online discussion is still a problem that needs to be actively explored and solved in the future. There are still some shortcomings in the English smart class, such as the flood of 
information, the shallow nature of communication and interaction and too much reliance on digital technology, etc. Too many learning materials and tasks have squeezed students' spare time. Teachers may pursue the perfection of micro-lessons deliberately while ignore the principle of "teaching as the guide and learning as the main body". These problems will need to be constantly reflected and improved in our smart class exploration. However, what the smart class brings us the greatest value is "change", and the development of educational informatization will promote the blossoming of smart class, smart teachers and smart campus.

\section{REFERENCES}

[1] Dickinson,L.Self-Instruction learning[M].Cambridge:Cambridge University Press, 1987.

[2] BensonK.The Philosophy and Politics LearnerAutonomy[M].London: Longman, 1997.

[3] Tang Yewei. The Construction Method and Case Study of Smart Class Based on the Information Technology Environment [J]. China Audiovisual Education,2014,(11):23-29.

[4] Sun Shuhui,Liu Bangqi.Smart Class Model Based on the Analysis of Dynamic Learning Data [J]. China Education Information, 2015,(22):21-24.

[5] Cui Xiaohui,Zhu Xuan. The Concept, Characteristic and Implementation Framework of the Smart Class Based on the Information Technology Environment [J]. Continuing Education,2016,30(05):50-52. 